DOI: 10.20472/TEC.2019.008.008

\author{
GABRIELA DUBCOVÁ \\ University of Economics in Bratislava, Slovakia \\ L'UBICA FOLTÍNOVÁ \\ University of Economics in Bratislava, Slovakia
}

\title{
MODEL OF THE EDUCATION FOR ADULTS IN SLOVAKIA
}

\begin{abstract}
:
Education of the adult population - very important permanent process for the development of each country and sustainable successful development of each population. Active Aging and Education of the Adult Population. Global Population Pyramid in 2002 and 2025. Global Population Pyramid in 2002 and 2025. Determinants of Active Ageing. Principles of Active Ageing. Challenges of Adult Learning. Characteristics of Adult Education. Scope of adult education. Principles of Adult Education. Reasons for Education of the Adult Population. Standards for Adult Education. Advantages and Barriers of Adult Education. Educational Policies for Education of the Adult Population. Principle of Functioning Model of Education for Adults. Real Results of Adult Education in Practice. Conclusions and Recommendations.
\end{abstract}

\section{Keywords:}

Adult Population, Education for Adults, Active Ageing, Adult Learning, Educational Policies, Lifelong Learning

JEL Classification: 123,125 


\section{Introduction}

\begin{abstract}
"Population ageing is first and foremost a success story for public health policies as well as social and economic development."...
\end{abstract}

Gro Harlem Brundtland,

Director-General, World Health Organization, 1999

Education of the adult population is a very important permanent process for the development of each country and each nation as it could seriously increase the productivity, social structure of each nation and support sustainable successful development of each population. Education of the adult population provides opportunities of socialization, relationship humanization of adult people, personal development, employment, resulting in the country's economic growth. Education of the adult population also generates higher primary enrollments - as educated parents are more focused on central interest to educate their children.

Each educated and skilled adult person will be gainfully employed in an organization/institution or will be active in business; with direct positive impact on the nation's economy. Education of the adult population also supports increasing the population's health and hygiene level and has positive effect on higher standards of living and minimizing misery.

Objective of the research:

- To describe the importance of education for adults

- To analyze general attributes of education of the adult population

- To present official educational policies for education of the adult population

- To explain the functioning model of education for adults and its real results in practice

\section{Active Aging and Education of the Adult Population}

The World Health Organization argues that countries can afford to get old if governments, international organizations and civil society enact "active ageing" policies and programs that enhance the health, participation and security of elderly citizens. The time to plan and to act is now. ${ }^{1}$ Real development of the aging population is visible in the following picture (As the proportion of children and young people declines and proportion of people aged 60 and over increases, triangular population pyramid of 2002 will be replaced for a more cylinder-like structure in 2025):

\footnotetext{
${ }^{1}$ https://www.who.int/ageing/publications/active_ageing/en/ [04-07-2019]
} 


\section{Figure 1: Global Population Pyramid in 2002 and 2025}

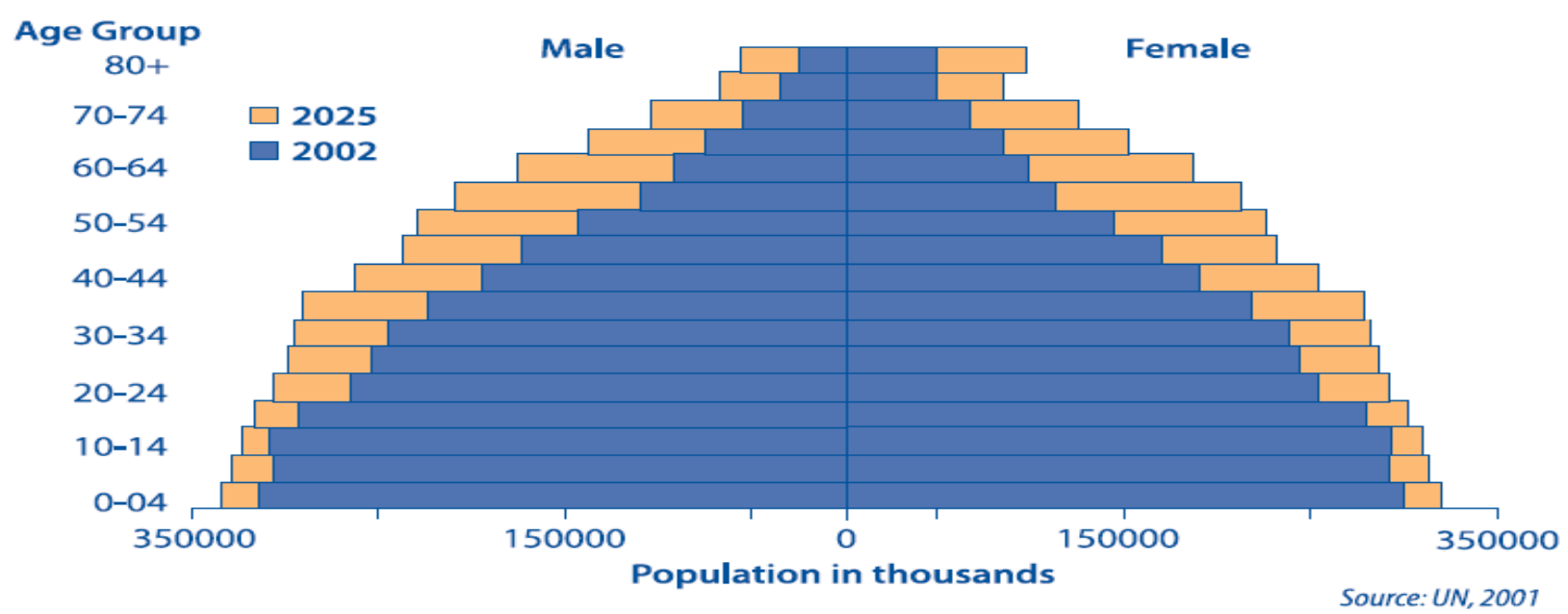

Source: Active ageing: a policy framework. https://www.who.int/ageing/publications/active_ageing/en/ [0407-2019]

In all the countries, and predominantly in the developing countries, measures to help elderly persons remaining healthy and active are a necessity, not a luxury. Based on this, education of the adult population is one the most important ways to support personal motivation and involvement to have active ageing, physical and mental health, social inclusion and economic conditions.

\subsection{Definitions of Active Ageing}

The WHO: "Active ageing is the process of optimizing opportunities for health, participation and security in order to enhance quality of life as people age." ${ }^{2}$ The credible MuseumNext: "Active ageing means being active and engaged before and during retirement. This can include physical activity such as fitness classes. But it also encompasses mental exercises and lifelong learning. Active ageing can be key to staying healthy, both physically and mentally."3

The Università Cattolica del Sacro Cuore in Milan:...."young seniors", the definition used by the team of sociologists, demographic researchers, and psychologists from the Università Cattolica del Sacro Cuore in Milan, to define the age group of people between 65 and 74 years old, which includes those people who are no longer young, but neither are they very old. They are the focal points of the so-called active ageing. Or rather: ageing that keeps people active. If older people are no longer just older people, even ageing will never be the same again." ${ }^{4}$

The OECD: The definition is focused on the transition from work to retirement. It has been suggested that this does takes account of the environment that influences health and well-being across the span of a life. ${ }^{5}$

International Council on Active Aging: „Active aging promotes the vision of all the individualsregardless of age, socioeconomic status or health-fully engaging in life within all seven

\footnotetext{
${ }^{2}$ https://www.who.int/ageing/publications/active_ageing/en/ [04-07-2019]

${ }^{3} \mathrm{https}: / / \mathrm{www} . \mathrm{museumnext.com/2019/04/active-ageing-and-the-open-air-museum/.} \mathrm{[04-07-2019]}$

${ }^{4} \mathrm{https} / / / \mathrm{www} . \mathrm{morningfuture.com/en/article/2017/08/04/active-aging-profiles-senior-work-rosina/65/} \mathrm{[04-07-2019]}$

${ }^{5}$ https://www.oecd.org/els/health-systems/48245594.pdf. [04-07-2019]
} 
dimensions of wellness: emotional, environmental, intellectual/cognitive, physical, professional/vocational, social and spiritual." 6

For the quality of daily live (professional, family and social) of each person the actual situation is very important (the combination) of the determinants of active ageing:

Figure 2: The Determinants of Active Ageing

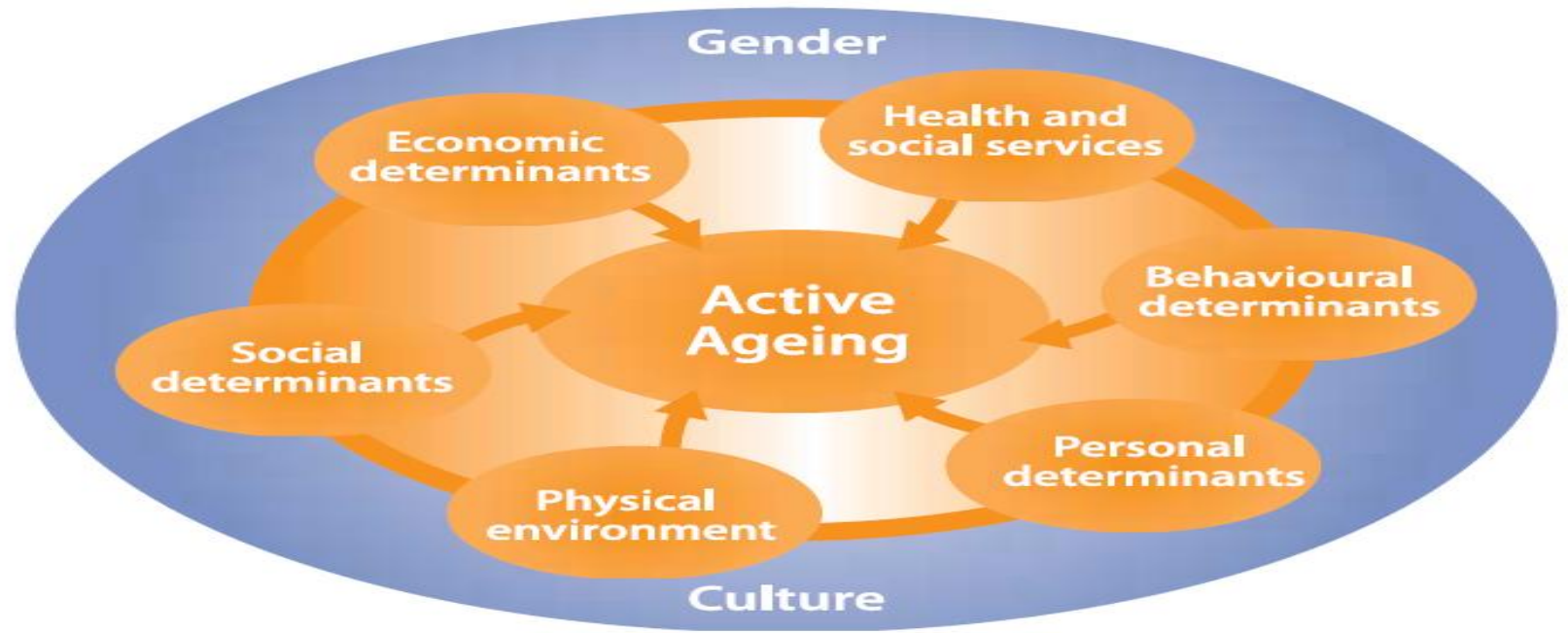

Source: Active ageing: a policy framework. https://www.who.int/ageing/publications/active_ageing/en/ [0407-2019]

\footnotetext{
${ }^{6}$ https://www.icaa.cc/activeagingandwellness/what-is-active-aging.htm. [04-07-2019]
} 


\subsection{Basic Principles of Active Aging}

International Council on Active Aging is the author of Principles of Active Aging to help governments, producers and service providers, entrepreneurs, employers, and the industry related to healthcare in how they respond to population aging. After the institutionalization of these principles, enterprises, organizations and institutions will be able to create a basis for their efforts and sustainable active, engaged living for people of all any age. Nine Principles of Active Aging related to this follow:

Figure 3: 9 Principles of Active Ageing

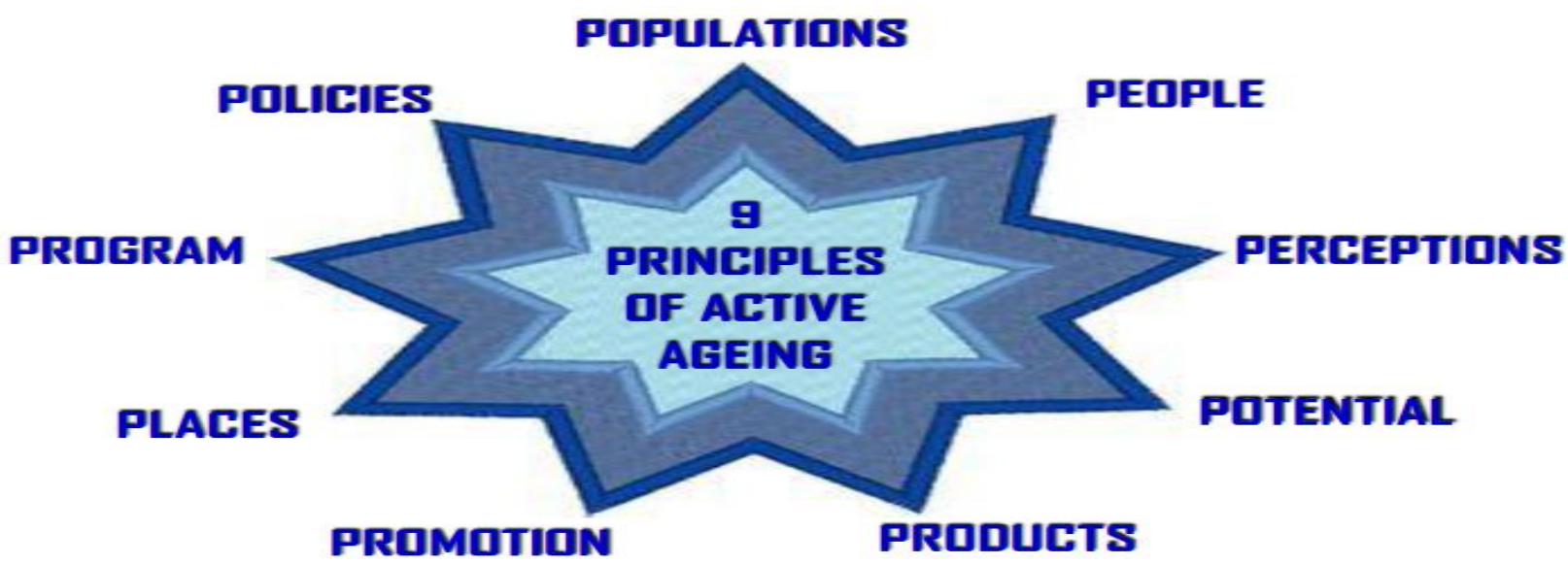

\begin{tabular}{|l||l||}
\hline \multicolumn{2}{|c|}{ DESCRIPTION: 9 PRINCIPLES OF ACTIVE AGEING } \\
\hline $\begin{array}{l}\text { Area of the } \\
\text { Principle }\end{array}$ & \multicolumn{1}{c|}{ Content of the Principle } \\
\hline \hline Populations & Diverse population of older adults requires diverse solutions. \\
\hline People & $\begin{array}{l}\text { Trained and committed individuals are needed to meet the needs, capabilities, expectations, dreams and } \\
\text { desires of older adults. }\end{array}$ \\
\hline Perceptions & Ageism and negative stereotypes of aging impede an inclusive society. \\
\hline Potential & Population aging creates new economies. \\
\hline Products & Products and services are needed that tailor to older adult needs and expectations. \\
\hline Promotions & Older adults are a key market to attract. \\
\hline Places & Environments must be constructed to enable multiple functional abilities. \\
\hline Policies & Human rights of older adults should be protected. \\
\hline Program: & Seven dimensions of wellness anchor the principles. \\
\hline
\end{tabular}

Source: https://www.icaa.cc/activeagingandwellness/activeaging.htm [04-07-2019]

\subsection{Core Attributes of Education of the Adult Population}

Regarding the program, Active Ageing is the main direction of the involvement of the adult population to make quality and attractive education system for this age group of people.

\section{Challenges of Adult Learning}

This type of education brings lot of challenges: 
- Adults have many obligations and responsibilities, making it difficult for them to take out time for educational activities.

- Some may have responsibility towards family and some may be employed in different sectors.

- Women who are engaged in everyday household chores may find it difficult to attend education programs.

- Lack of proper transport in the area can also act as a hindrance to Adult Education.

- Apart from that, lack of learning desire, lack of interest, lack of information and absence of the required infrastructure and skilled manpower are some of the impediments to adult education.

- Some adults may just be shy to join any educational program, because of their age or for the fear of family and friends.

\section{Characteristics of Adult Education}

Learning process of the adult population is identifiable with following specific educational characteristics:

- Adults are autonomous and self-directed

- Adults have aggregated and accumulated potential of life experiences and knowledge

- Adults are target orientated

- Adults are focused on relevance - they must expect a reason for learning something

- Adults are practical persons

- Adults need to be respected

\section{Scope of adult education}

The most important scope of education of the adult population:

- The need for adult learning and continuing education is due to following factors:

- Changing social trends

- Population mobility

- Changing role of hospital

- Health status

- Employment and empowerment of women

\section{Principles of Adult Education}

For adult learning, we can identify 7 special educational principles:

Figure 4: 7 Principles of Adult Education

\begin{tabular}{|l||l|}
\hline \multicolumn{2}{|c|}{ PRINCPLES OF ADULT EDUCATION } \\
\hline \multicolumn{1}{|c|}{ Area of the Principle } & \multicolumn{1}{c|}{ Content of the Principle } \\
\hline 1/Adults must want to learn & $\begin{array}{l}\text { They learn effectively only when they have a strong inner motivation to develop } \\
\text { new skill or acquire a particular type of knowledge. }\end{array}$ \\
\hline $\begin{array}{l}\text { 2/Adults will learn only what they feel } \\
\text { they need to learn }\end{array}$ & $\begin{array}{l}\text { Adults are practical in their approach to learning; they want to know: "How is } \\
\text { this going to help me right now?" }\end{array}$ \\
\hline 3/Adults learn by doing & Children learn by doing, but active participation is more important among adults. \\
\hline $\begin{array}{l}\text { 4/Adult learning focused on problems } \\
\text { and the problems must be realistic }\end{array}$ & $\begin{array}{l}\text { Children learn skills sequentially. Adults start with a problem and then work to } \\
\text { find a solution. }\end{array}$ \\
\hline 5/Experience affects adult learning & Adults have more experience than children. This can be asset and a liability. \\
\hline $\begin{array}{l}\text { 6/Adults learn best in an informal } \\
\text { situation }\end{array}$ & $\begin{array}{l}\text { Children have to follow a curriculum. Often, adults learn only what they feel they } \\
\text { need to know. }\end{array}$ \\
\hline 7/Adult want guidance & Adults want information that will help them improve their situation or that of their \\
\hline
\end{tabular}


children. They do not want to be told what to do. They want to choose options based on their individual needs.

Source: https://www.slideshare.net/AshokBishnoi1/in-service-education [04-07-2019]

\section{Reasons for Education of the Adult Population}

Regarding the relevant attributes of adult learning, we are able to identify interesting combination of the important reasons for education of the adult population ( $3 \times 10)$ :

\section{Figure 5: Reasons for Education of the Adult Population}

\begin{tabular}{|c|c|c|c|}
\hline \multicolumn{4}{|c|}{ REASONS FOR EDUCATION OF THE ADULT POPULATION (3x10) } \\
\hline No. & Stonebridge Associated Colleges & Wilderness Education Association & $\begin{array}{l}\text { Getting Smart } \\
\text { Association }\end{array}$ \\
\hline 1. & $\begin{array}{l}\text { Adult education helps us keep up } \\
\text { with the changes in the world }\end{array}$ & $\begin{array}{l}\text { Adults need to adapt to social and technological changes } \\
\text { if they are to keep up with developments. }\end{array}$ & $\begin{array}{c}\text { Skill Up } \\
\text { (Functionality). }\end{array}$ \\
\hline 2. & $\begin{array}{l}\text { Adult education helps us keep up } \\
\text { with the changes in ourselves }\end{array}$ & $\begin{array}{l}\text { Being able to read and write English fluently and to use } \\
\text { numbers accurately are basic skills, not only for jobs but } \\
\text { for daily life. }\end{array}$ & $\begin{array}{l}\text { Purpose and } \\
\text { Path. }\end{array}$ \\
\hline 3. & $\begin{array}{l}\text { Adult education is essential for } \\
\text { retraining }\end{array}$ & $\begin{array}{l}\text { All government services are now designed to be 'digital } \\
\text { by default', for adult people too. }\end{array}$ & $\begin{array}{l}\text { Passions and } \\
\text { Life } \\
\text { Satisfaction. }\end{array}$ \\
\hline 4. & Learning keeps the mind active & $\begin{array}{c}\text { Young people leaving school now without specific grades } \\
\text { in GCSE English and Maths have to reach those } \\
\text { standards. }\end{array}$ & Employability. \\
\hline 5. & $\begin{array}{l}\text { Learning keeps you busy socially, } \\
\text { too. }\end{array}$ & $\begin{array}{l}\text { Many school leavers with low attainment levels will } \\
\text { become parents of children who follow the same pattern. }\end{array}$ & $\begin{array}{l}\text { Economic } \\
\text { Imperative. }\end{array}$ \\
\hline 6. & Education feeds a person's creativity & $\begin{array}{l}\text { Education is not just for work. It promotes health and } \\
\text { wellbeing, reducing isolation for older people and } \\
\text { keeping their minds active, while harnessing the benefits } \\
\text { of their experience and knowledge. }\end{array}$ & Leadership. \\
\hline 7. & $\begin{array}{l}\text { Further education sets a good } \\
\text { example for future generations }\end{array}$ & $\begin{array}{c}\text { Low levels of participation in voting means that } \\
\text { democracy is not representative. Learning about how } \\
\text { political systems work is important if we are to engage } \\
\text { people in civic life. }\end{array}$ & Transferability. \\
\hline 8. & $\begin{array}{l}\text { Adult education gives people a } \\
\text { second chance }\end{array}$ & $\begin{array}{l}\text { All aspects of life depend upon adaptability and active } \\
\text { minds. Learning to learn is a skill in itself. }\end{array}$ & $\begin{array}{l}\text { Social } \\
\text { Awareness and } \\
\text { Perspective. }\end{array}$ \\
\hline 9. & We are living much longer & $\begin{array}{c}\text { Education is a means to address inequality in many } \\
\text { forms. }\end{array}$ & Practicality. \\
\hline 10. & $\begin{array}{l}\text { Adult learning is good for the } \\
\text { economy }\end{array}$ & $\begin{array}{l}\text { Learning is one of life's greatest pleasures. Art, literature, } \\
\text { history and culture should be available to everyone and } \\
\text { not only those who can afford them. }\end{array}$ & Longevity. \\
\hline
\end{tabular}

Source: https://www.stonebridge.uk.com/blog/education-teaching-and-coaching/adult-education; https://annwalkerwea.wordpress.com/2015/10/11/10-reasons-to-save-adult-education/; https://www.gettingsmart.com/2017/01/10-reasons-why-lifelong-learning-is-the-only-option/\# [04-07-2019]

\section{Standards for Adult Education}


The National Institute for Literacy (NIFL) is the author of the EFF Standards for Adult Literacy and Lifelong Learning. NIFL then specified content standards for each theme and is now in the process of developing performance assessments aligned with the content standards, with the central aim to identify the most attractive and important themes of family, community, work, and lifelong learning as the main purposes for which adults enroll in adult basic education programs. These EFF Standards are applicable for all the related types of education of adult population.

\section{Figure 6: Standards for Education of Adult Population}

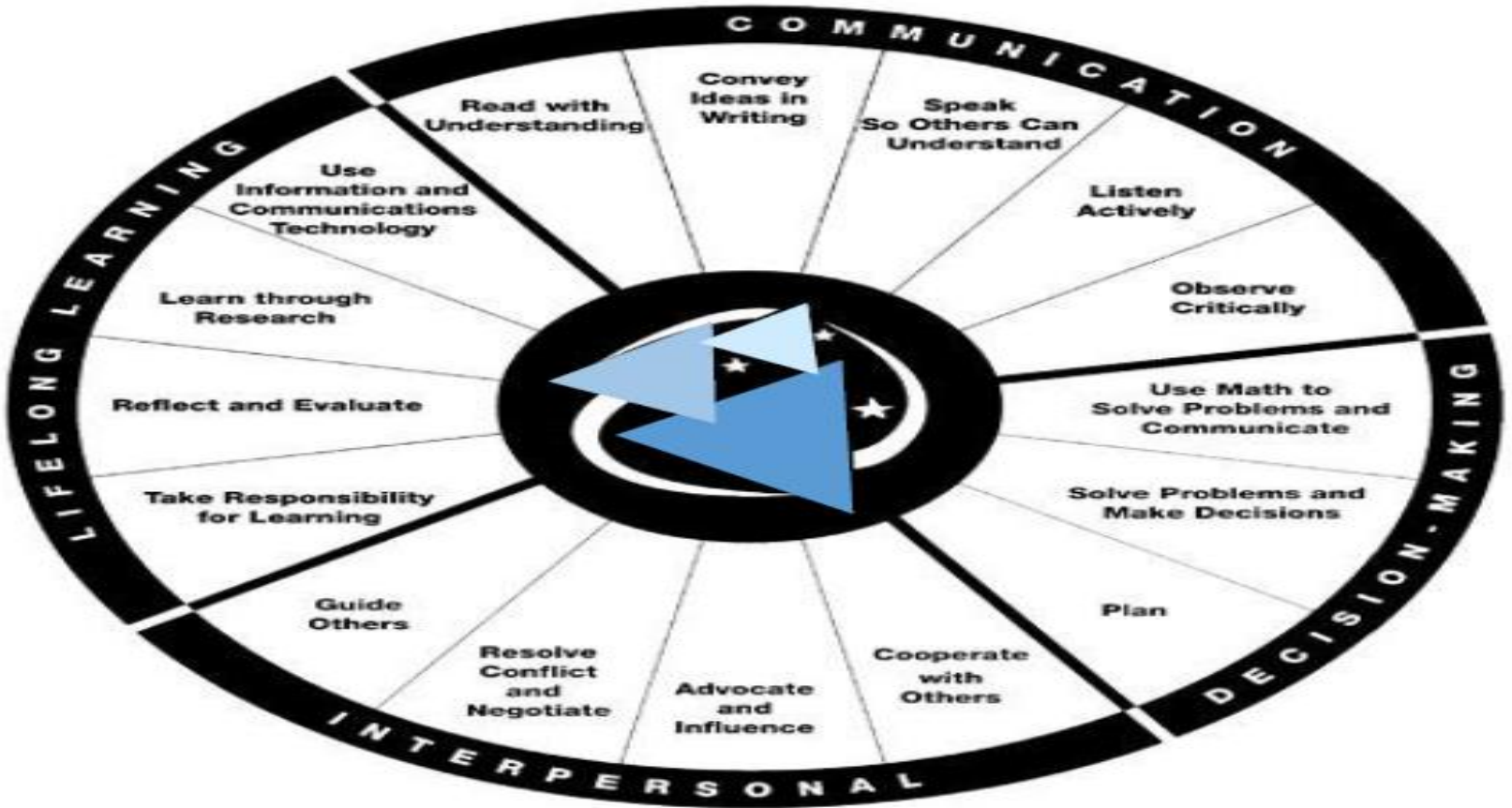

Source: https://www.nap.edu/read/10366/chapter/7\#86 [04-07-2019]

\section{Advantages and Barriers of Adult Education}

The most visible positives and negatives of adult education:

\section{Figure 7: Advantages and Barriers of Adult Education}

\begin{tabular}{|l|l|}
\hline \multicolumn{1}{|c|}{ Advantages of Adult Education (+) } & Barriers of Adult Education (-) \\
\hline - Improved skills and knowledge. & - Feeling out of place generally because of the age \\
- Opportunity to learn and communicate. & difference. \\
- Increase in individual productivity. & $\begin{array}{l}\text { Shortage of time as one has to balance between } \\
\text { - Increases employability of adults. }\end{array}$ \\
- Provides a lost opportunity to study and obtaining a & $\begin{array}{l}\text { - Fear of uncertainty, which is absent in regular young } \\
\text { students. }\end{array}$ \\
- certificate. & $\begin{array}{l}\text { - It takes time to adjust to your schedules of studies or } \\
\text { learning. }\end{array}$ \\
- livelihood. & - Sometimes might lack the formal student - teacher -like \\
- Improves general awareness of adults. & Makes the adults more confident and communicative. \\
- Improves the social network of the society. & intion; especially in distance learning. \\
- Healthy and hygienic living conditions. &
\end{tabular}


- Eradicates poverty by raising employability.

- Gives employees a chance to further progress in their respective fields.

- Gives the women a chance to progress.

- Provides higher salary and career options.

Source: https://www.indiacelebrating.com/article/importance-of-education-for-adults/ [04-07-2019]

\section{Educational Policies for Education of Adult Population}

In this part, we present the short review of the official educational policies for learning of the adult population.

Figure 8: Official Policies for Learning of the Adult Population

\begin{tabular}{|c|c|c|c|}
\hline \multicolumn{4}{|c|}{ DECLARATION OF THE POLICIES FOR EDUCATION OF THE ADULT POPULATION } \\
\hline No. & Institution & Policy* & Link \\
\hline 1. & $\begin{array}{c}\text { EU Commissariat for } \\
\text { Education, Culture, } \\
\text { Youth and Sport }\end{array}$ & $\begin{array}{l}\text { EU Policy in the Field of } \\
\text { Adult Learning }\end{array}$ & $\begin{array}{l}\text { https://ec.europa.eu/education/policies/eu-policy-in-the-field- } \\
\text { of-adult-learning_en }\end{array}$ \\
\hline 2. & $\begin{array}{l}\text { Ministry of Education, } \\
\text { Science, Research } \\
\text { and Sport of the SR }\end{array}$ & Lifelong Learning Strategy & $\begin{array}{c}\text { https://eacea.ec.europa.eu/national- } \\
\text { policies/eurydice/content/lifelong-learning-strategy-72_en }\end{array}$ \\
\hline 3. & OECD & Adult Learning Systems & $\begin{array}{c}\text { http://www.oecd.org/els/emp/adult-learning-systems- } \\
\text { 2019.pdf }\end{array}$ \\
\hline 4. & World Bank & Lifelong Learning & $\begin{array}{l}\text { ttps://elibrary.worldbank.org/doi/full/10.1596/978-1-4648- } \\
\text { 1328-3_ch4 }\end{array}$ \\
\hline 5. & UN & $\begin{array}{l}\text { Goal } 4 \text { Quality Education } \\
\text { (in The SDG) }\end{array}$ & https://sustainabledevelopment.un.org/?menu=1300 \\
\hline 6. & UIL UNESCO & Lifelong Learning & http://uil.unesco.org/lifelong-learning \\
\hline 7. & UNDP & Goal 4: Quality Education & $\begin{array}{l}\text { https://www.undp.org/content/undp/en/home/sustainable- } \\
\text { development-goals/goal-4-quality-education.html }\end{array}$ \\
\hline 8. & ILO & Lifelong Learning & $\begin{array}{l}\text { http://www.ilo.org/global/topics/skills-knowledge-and- } \\
\text { employability/lifelong-learning/lang--en/index.htm }\end{array}$ \\
\hline 9. & CSR Europe & $\begin{array}{l}\text { Active Ageing through } \\
\text { Adult Learning }\end{array}$ & $\begin{array}{c}\text { https://www.csreurope.org/active-ageing-through- } \\
\text { adult-learning\#.XR-ttY9nrlU }\end{array}$ \\
\hline
\end{tabular}

Source: Own adjustment based on real data of the related policies

\section{Model of Education for Adults}

\subsection{Principle of Functioning Model of Education for Adults}

On the basis of official education policy of the Ministry of Education, Science, Research and Sport of the SR, the Model of Education for Adults is created with 4 levels:

1/European Union Commissariat for Education, Culture, Youth and Sport - the most important institution for internal state education policy of each member country of the EU;

2/The Ministry of Education, Science, Research and Sport of the SR - the author of all detailed policies from the EU level into national country level, incl. Lifelong Learning and Adult Education policy, with related responsibility for accreditation process of the study programs for education of the adult population.

3/ Further Education Institutions with the Accredited Study Programs (ISCED level 3 - ISCED level 8), predominantly Universities of the Third Age and other Education Institutions in the SR. 
4/ Individual Adult Student - first, there must be personal motivation and involvement to have active ageing with education.

It is characteristic for this system to intensively cooperate with the Association of Universities of the Third Age of Slovakia and Association of Adult Education Institutions in the SR.

\section{Figure 9: Model of Education for Adults}

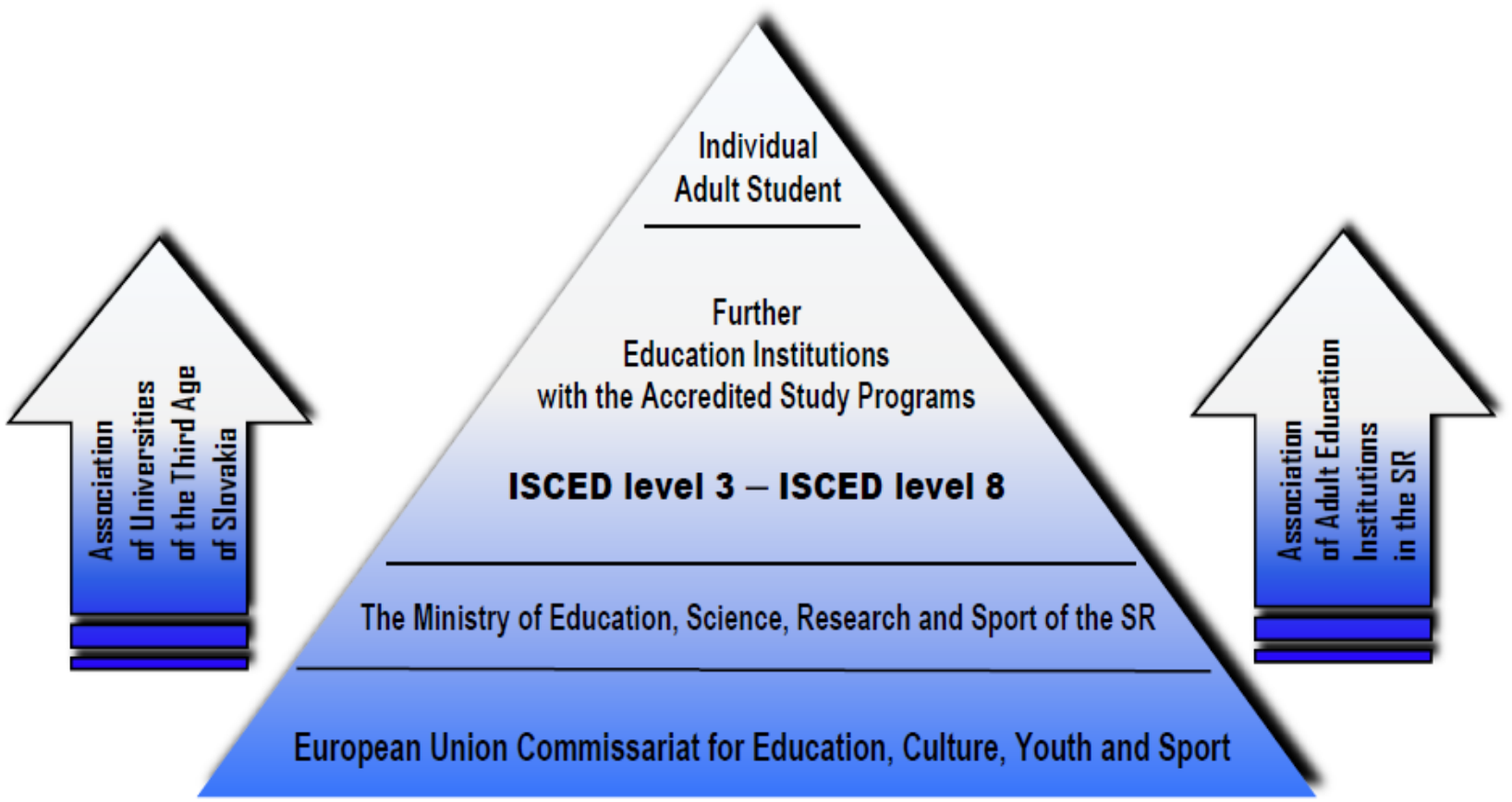

Source: Own adjustment

\subsection{Real Results of Adult Education in the Practice}

The potential of the existing Model of Education for Adults in the SR is huge, but the reality is different.

\section{Figure 10: Priorities for Adult Learning}

\begin{tabular}{|c||c|c|c|}
\hline \multicolumn{4}{|c|}{ PRIORITIES FOR ADULT LEARNING } \\
\hline $\begin{array}{c}\text { Dimension } \\
\text { Description/Limit }\end{array}$ & $\begin{array}{c}\text { The Lowest Value } \\
\text { [Country \& Value] }\end{array}$ & $\begin{array}{c}\text { Slovakia Position } \\
\text { [Position \& Value] }\end{array}$ & $\begin{array}{c}\text { The highest Value } \\
\text { [Country \& Value] }\end{array}$ \\
\hline $\begin{array}{c}\text { 1) Urgency: How pressing is the need to } \\
\text { update the adult learning system? } \\
\text { [least urgent } \rightarrow \text { most urgent] }\end{array}$ & New Zealand (0.1) & $(20,0.47)$ & Portugal (0.6) \\
\hline $\begin{array}{c}\text { 2) Coverage: To what extent are people and } \\
\text { firms engaged in learning? } \\
{[\text { lowest coverage } \rightarrow \text { highest coverage] }}\end{array}$ & Hungary (0.1) & $(9,0.45)$ & United States (0.8) \\
\hline $\begin{array}{c}\text { 3) Inclusiveness: How inclusive are adult } \\
\text { learning opportunities? } \\
\text { [least inclusive } \rightarrow \text { most inclusive] }\end{array}$ & Netherlands (0.3) & $(2,0.33)$ & Greece (0.8) \\
\hline 4) Flexibility and Guidance: Are adult learning & Hungary (0.1) & $(7,0.35)$ & Luxembourg (0.8) \\
\hline
\end{tabular}




\begin{tabular}{|c|c|c|c|}
\hline $\begin{array}{l}\text { opportunities flexible and is guidance } \\
\text { readily available? } \\
\text { [weakest flexibility and guidance } \rightarrow \text { strongest } \\
\quad \text { flexibility and guidance] }\end{array}$ & & & \\
\hline $\begin{array}{l}\text { 5) Alignment with Skill Needs: Is adult learning } \\
\text { aligned with labour market needs? } \\
\qquad \text { [least aligned } \rightarrow \text { most aligned] }\end{array}$ & Japan (0.2) & $(8,0.48)$ & Denmark (0.8) \\
\hline $\begin{array}{l}\text { 6) Perceived Training Impact: What is the } \\
\text { impact of adult learning? } \\
\qquad \begin{array}{l}\text { [lowest perceived impact } \rightarrow \\
\text { highest perceived impact] }\end{array}\end{array}$ & Netherlands (0.2) & $(24,0.55)$ & Chile (0.8) \\
\hline $\begin{array}{l}\text { 7) Financing: How well is the adult learning } \\
\text { system financed? } \\
\text { [weakest financing arrangements } \rightarrow \text { strongest } \\
\text { financing arrangements }\end{array}$ & Hungary (0.1) & $(7,0.33)$ & Japan (0.8) \\
\hline
\end{tabular}

Source: Own adjustment based on http://www.oecd.org/els/emp/skills-and-work/adult-learning/dashboard. htm. [04-07-2019]

The analysis of data from the OECD reports focused on quality adult education with 7 priority indicators: urgency, coverage, inclusiveness, flexibility and guidance, alignment with skill needs, perceived training impact, and financing presents complicated situation in the SR, in comparison to other countries.

Slovakia has the worst position $(2,0.33)$ in the indicator "Inclusiveness" (how equitable participation in adult learning is across countries) and the best position $(24,0.55)$ in the indicator "Perceived Training Impact" (What is the impact of adult learning?). However, other countries of V4 are in a better position, again: the CR 0.6 , Poland 0.72 and Hungary 0.75 .

The identical situation occurs when we diagnose development of the participation rate (\%) in education and training by age in the V4 countries during the years 2002 - 2018. Slovakia:

- has the lowest participation rates from among the V4 countries in 2018,

- the situation has worsened over the years,

- the negative trend of development is long-term.

Figure 11: Participation Rate (\%) in Education and Training by Age in the V4 


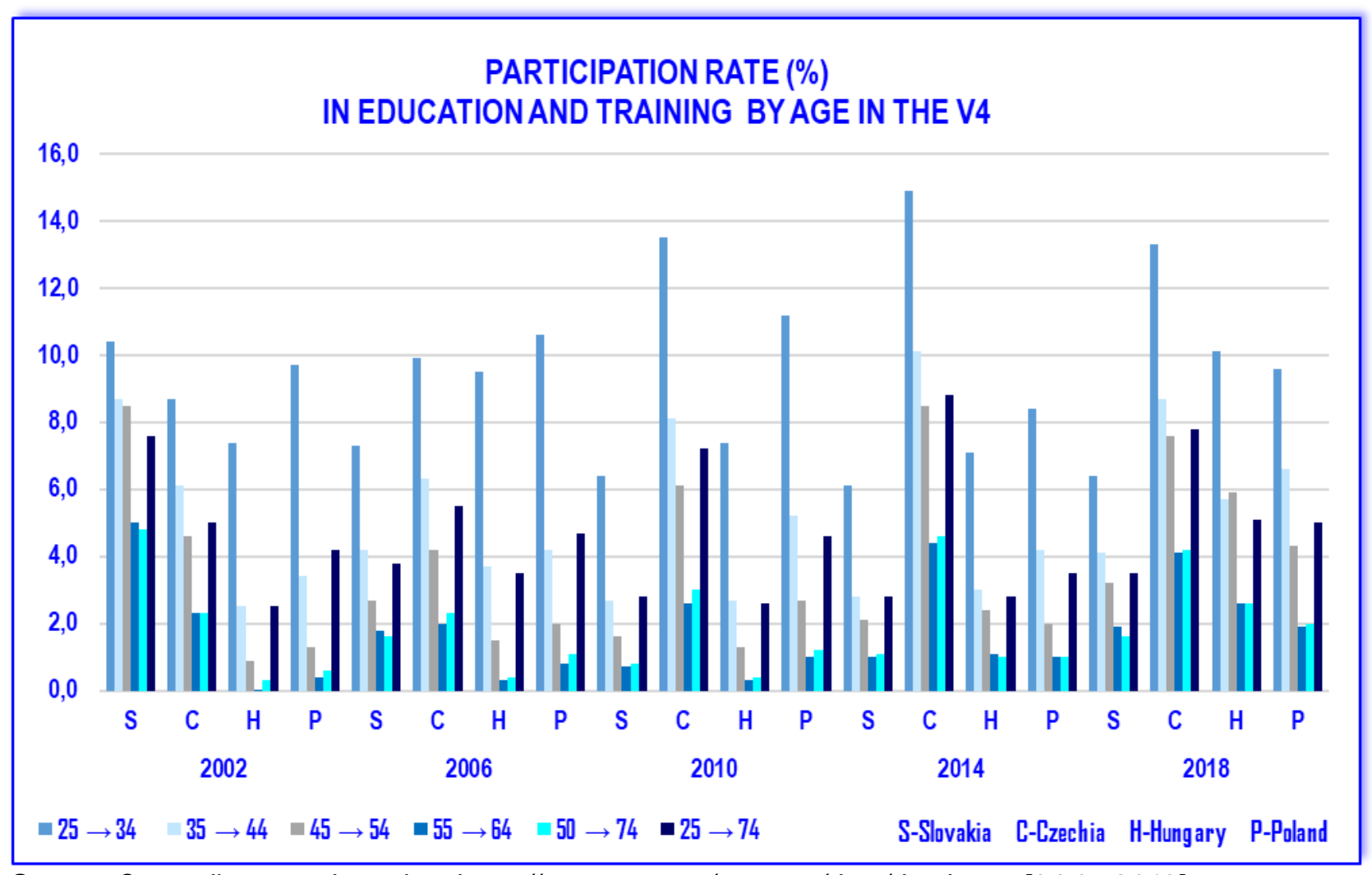

Source: Own adjustment based on https://ec.europa.eu/eurostat/data/database. [04-07-2019]

The presented visual development in specific values:

Figure 12: Development of the Participation Rate (\%) in Education and Training by Age in the V4 during Years $2002-2018$

\begin{tabular}{|c|c|c|c|c|c|c|c|c|c|c|c|c|c|c|c|c|c|c|c|c|}
\hline \multicolumn{21}{|c|}{$\begin{array}{c}\text { DEVELOPMENT OF THE PARTICIPATION RATE (\%) } \\
\text { IN EDUCATION AND TRAINING BY AGE IN THE V4 DURING YEARS } 2002 \text { - } 2018\end{array}$} \\
\hline \multirow{2}{*}{$\begin{array}{l}\text { AGE/TIME } \\
\text { (in years) }\end{array}$} & \multicolumn{4}{|c|}{\begin{tabular}{|l|}
2002 \\
\end{tabular}} & \multicolumn{4}{|c|}{2006} & \multicolumn{4}{|c|}{2010} & \multicolumn{4}{|c|}{\begin{tabular}{|l|}
2014 \\
\end{tabular}} & \multicolumn{4}{|c|}{2018} \\
\hline & $S$ & $\mathbf{C}$ & $\mathrm{H}$ & $\mathbf{P}$ & $\mathrm{S}$ & $C$ & $\mathrm{H}$ & $\mathbf{P}$ & $S$ & $\mathbf{C}$ & $\mathrm{H}$ & $\mathbf{P}$ & $S$ & C & $\mathrm{H}$ & $\mathbf{P}$ & $S$ & $\mathrm{C}$ & $\mathrm{H}$ & $\mathbf{P}$ \\
\hline $25 \rightarrow 34$ & 10,4 & 8,7 & 7,4 & 9,7 & 7,3 & 9,9 & 9,5 & 10,6 & 6,4 & 13,5 & 7,4 & 11,2 & 6,1 & 14,9 & 7,1 & 8,4 & 6,4 & 13,3 & 10,1 & 9,6 \\
\hline $35 \rightarrow 44$ & 8,7 & 6,1 & 2,5 & 3,4 & 4,2 & 6,3 & 3,7 & 4,2 & 2,7 & 8,1 & 2,7 & 5,2 & 2,8 & 10,1 & 3,0 & 4,2 & 4,1 & 8,7 & 5,7 & 6,6 \\
\hline $45 \rightarrow 54$ & 8,5 & 4,6 & 0,9 & 1,3 & 2,7 & 4,2 & 1,5 & 2,0 & 1,6 & 6,1 & 1,3 & 2,7 & 2,1 & 8,5 & 2,4 & 2,0 & 3,2 & 7,6 & 5,9 & 4,3 \\
\hline $55 \rightarrow 64$ & 5,0 & 2,3 & 0,0 & 0,4 & 1,8 & 2,0 & 0,3 & 0,8 & 0,7 & 2,6 & 0,3 & 1,0 & 1,0 & 4,4 & 1,1 & 1,0 & 1,9 & 4,1 & 2,6 & 1,9 \\
\hline $50 \rightarrow 74$ & 4,8 & 2,3 & 0,3 & 0,6 & 1,6 & 2,3 & 0,4 & 1,1 & 0,8 & 3,0 & 0,4 & 1,2 & 1,1 & 4,6 & 1,0 & 1,0 & 1,6 & 4,2 & 2,6 & 2,0 \\
\hline $25 \rightarrow 49$ & 9,3 & 7,0 & 4,3 & 5,5 & 5,3 & 7,7 & 5,8 & 6,5 & 4,1 & 10,1 & 4,4 & 7,5 & 4,0 & 11,8 & 4,4 & 5,7 & 4,9 & 10,2 & 7,4 & 7,5 \\
\hline $25 \rightarrow 64$ & 8,5 & 5,6 & 2,9 & 4,2 & 4,3 & 5,8 & 4,0 & 4,7 & 3,1 & 7,8 & 3,0 & 5,2 & 3,1 & 9,6 & 3,3 & 4,0 & 4,0 & 8,5 & 6,0 & 5,7 \\
\hline $25 \rightarrow 74$ & 7,6 & 5,0 & 2,5 & 4,2 & 3,8 & 5,5 & 3,5 & 4,7 & 2,8 & 7,2 & 2,6 & 4,6 & 2,8 & 8,8 & 2,8 & 3,5 & 3,5 & 7,8 & 5,1 & 5,0 \\
\hline
\end{tabular}

Source: Own adjustment based on https://ec.europa.eu/eurostat/data/database. [04-07-2019] 


\section{Conclusions and Recommendations}

After the analysis, we can define conclusions and formulate recommendations for the improvement of the status quo.

\subsection{Conclusions}

- World and European institutions pay close attention to the issue of active aging.

- Active aging promotes the vision of all individuals-regardless of age, socioeconomic status or health-fully engaging in life within all seven dimensions of wellness: emotional, environmental, intellectual/cognitive, physical, professional/vocational, social and spiritual.

- Positive Trend - Extensive implementation of a sustainable development strategy through sustainable development goals including Goal 4 Quality Education.

- the complicated process of education of the adult population has demanding clients, stakeholders, financing, arrangement another immanent attributes

- Model of Education for Adults is created with 4 levels: 1/European Union Commissariat for Education, Culture, Youth and Sport 2/The Ministry of Education, Science, Research and Sport of the SR, 3/ Further Education Institutions with the Accredited Study Programs 4/ Individual Adult Student

- The identical situation occurs when we diagnose development of the participation rate (\%) in education and training by age in the V4 countries during years 2002 - 2018. Slovakia has the lowest participation rates from among the V4 countries last in the actual last year 2018 and this negative trend of development is long-term.

\subsection{Recommendations}

- To improve the national strategy for education to promote the model of education for adults in Slovakia more attractively and with higher efficiency;

- To apply the agreed policy of implementing the model of education for adults: the improved national strategy for education $\rightarrow$ to adopt the related laws $\rightarrow$ to apply a stimulating system of financial and economical tools $\rightarrow$ to implement a system of public authorities to coordinate the activities related to the functioning model of education for adults;

- To codify a stimulating system of financial and economical instruments (with adequate adaption of related laws): e.g. specialized system of the state supports, support grant schemes, tax breaks, tax deductions, etc.;

- To arrange consultation centres for the existing, new and potential organization/institution entities with goals to enhance and improve the system and networking helpful for the functioning model of education for adults;

- To start training and courses focused on the improvement of the functioning model of education for adults for organization/institution entities, public and students of andragogic as part of the education system of the SR;

- To inform, popularize or organize special awards and workshops for involved organization/institution entities into the improvement the functioning model of education for adults;

- To evoke and create a supporting network of mutual cooperation in professions' association, associations of employers, trade unions and related NPOs, NGOs to improve activities focused on the functioning model of education for adults;

- To initialize and apply efficient marketing tools for mass acceptance of the activities focused on the functioning model of education for adults, e.g. the national award, workshops, exhibitions and presentations (and other visualization forms) of the best practices in the area of education for adults, communication centre for education for adults, etc. 


\section{Acknowledgement}

This article has been prepared as one of the outputs of the research projects $1 / 0309 / 1850 \%$ and VEGA $1 / 0569 / 18$ 50\%.

\section{References}

HOLLINS, P. (2018). The Science of Self-Learning: How to Teach Yourself Anything, Learn More in Less Time, and Direct Your Own Education. ${ }^{\text {st }}$ Edition. Independently published, 2018. ISBN 978-1-73141673-5.

LONGWORTH, N. (2003). Lifelong Learning in Action: Transforming Education in the $21^{\text {st }}$ Century. $1^{\text {st }}$ Edition. Routledge, 2003. ISBN-13: 978-0-749-44013-8.

MERRIAM, S.H.; BIEREMA, L.L. (2013). Adult Learning: Linking Theory and Practice. $1^{\text {st }}$ Edition. JosseyBass Publishing, 2013. ISBN 978-1-11813-057-5.

MERRIAM, S.B.; CAFFARELLA, R.S. AND BAUMGARTNER, L.M. (2006). Learning in Adulthood : A Comprehensive Guide. 3rd Edition. John Wiley \& Sons Inc, 2006. ISBN: 978-0-787-97588-3.

PANITSIDES, E.P.; TALBOT, J.P. (2016). Lifelong Learning: Concepts, Benefits and Challenges. 1st Edition. NOVA, 2016. ISBN: 978-1-63484-617-2.

STÄHLI, A. (2006). Management Andragogics 2. Springer-Verlag Berlin Heidelberg, 2006. ISBN 978-3-54028973-9.

http://uil.unesco.org/lifelong-learning. [04-07-2019]

http://www.ilo.org/global/topics/skills-knowledge-and-employability/lifelong-learning/lang--en/index.htm. [04-07-2019]

http://www.oecd.org/els/emp/adult-learning-systems-2019.pdf. [04-07-2019]

http://www.oecd.org/els/emp/skills-and-work/adult-learning/dashboard.htm. [04-07-2019]

https://annwalkerwea.wordpress.com/2015/10/11/10-reasons-to-save-adult-education/. [04-07-2019]

https://eacea.ec.europa.eu/national-policies/eurydice/content/lifelong-learning-strategy-72_en.[04-072019]

https://ec.europa.eu/education/policies/eu-policy-in-the-field-of-adult-learning_en. [04-07-2019]

https://ec.europa.eu/eurostat/data/database. [04-07-2019]

https://sustainabledevelopment.un.org/?menu=1300. [04-07-2019]

https://www.csreurope.org/active-ageing-through-adult-learning\#.XR-ttY9nrlU. [04-07-2019]

https://www.gettingsmart.com/2017/01/10-reasons-why-lifelong-learning-is-the-only-option/\#.[04-072019]

https://www.icaa.cc/activeagingandwellness/activeaging.htm. [04-07-2019]

https://www.icaa.cc/activeagingandwellness/what-is-active-aging.htm. [04-07-2019]

https://www.indiacelebrating.com/article/importance-of-education-for-adults. [04-07-2019]

https://www.morningfuture.com/en/article/2017/08/04/active-aging-profiles-senior-work-rosina/65/[0407-2019]

https://www.museumnext.com/2019/04/active-ageing-and-the-open-air-museum/.[04-07-2019]

https://www.nap.edu/read/10366/chapter/7\#86. [04-07-2019]

https://www.oecd.org/els/health-systems/48245594.pdf. [04-07-2019] 
https://www.slideshare.net/AshokBishnoi1/in-service-education. [04-07-2019]

https://www.stonebridge.uk.com/blog/education-teaching-and-coaching/adult-education. [04-07-2019]

https://www.undp.org/content/undp/en/home/sustainable-development-goals/goal-4-qualityeducation.html. [04-07-2019]

https://www.who.int/ageing/publications/active_ageing/en/. [04-07-2019]

https://elibrary.worldbank.org/doi/full/10.1596/978-1-4648-1328-3_ch4. [04-07-2019] 